\title{
LABORATORY STUDY ON THE BIOREMEDIATION OF DIESEL OIL CONTAMINATED SOIL FROM A PETROL STATION
}

\author{
Adriano Pinto Mariano ${ }^{1,3 *}$; Ana Paula de Arruda Geraldes Kataoka²; Dejanira de Franceschi de Angelis²; \\ Daniel Marcos Bonotto ${ }^{1}$
}

${ }^{1}$ Instituto de Geociências e Ciências Exatas, Universidade Estadual Paulista, Rio Claro, SP, Brasil; ${ }^{2}$ Departamento de Bioquímica e Microbiologia, Instituto de Biociências, Universidade Estadual Paulista, Rio Claro, SP, Brasil; ${ }^{3}$ Programa de Recursos Humanos, Agência Nacional do Petróleo, Gás Natural e Biocombustíveis, Rio Claro, SP, Brasil

Submitted: July 24, 2006; Returned to authors for corrections: October 23, 2006; Approved: February 23, 2007.

\begin{abstract}
The purpose of the present study was to investigate possible methods to enhance the rate of aerobic biodegradation of hydrocarbons (ex-situ treatments). In this work, the bioremediation processes were applied to a sandy soil with a high level of contamination originated from the leakage of a diesel oil underground storage tank at a petrol station. Laboratory scale experiments (Bartha biometer flasks) were used to evaluate the biodegradation of the diesel oil. Enhancement of biodegradation was carried out through biostimulation (addition of nitrogen and phosphorus solutions or Tween 80 surfactant) and bioaugmentation (bacterial consortium isolated from a landfarming system). To investigate interactions between optimizing factors, and to find the right combination of these agents, the study was based on full factorial experimental design. Efficiency of biodegradation was simultaneously measured by two methods: respirometric (microbial $\mathrm{CO}_{2}$ production) and gas chromatography. Acute toxicity tests with Daphnia similis were applied for examination of the efficiency of the processes in terms of the generation of less toxic products. Results showed that all bioremediation strategies enhanced the natural bioremediation of the contaminated soil and the best results were obtained when treatments had nutritional amendment. Respirometric data indicated a maximum hydrocarbon mineralization of $19.8 \%$, obtained through the combination of the three agents, with a total petroleum hydrocarbons (TPH) removal of $45.5 \%$ in 55 days of treatment. At the end of the experiments, two predominant bacteria species were isolated and identified (Staphylococcus hominis and Kocuria palustris).
\end{abstract}

Key words: Bioremediation, Soil, Diesel Oil, Petrol Station

\section{INTRODUCTION}

Diesel oil leakages from underground storage tanks, distribution facilities and various industrial operations represent an important source of soil and aquifer contamination. This fuel is a complex mixture of normal, branched and cyclic alkanes, and aromatic compounds obtained from the middle-distillate fraction during petroleum separation (14).

Among several clean-up techniques available to remove petroleum hydrocarbons from the soil and groundwater, bioremediation processes are gaining ground due to their simplicity, higher efficiency and cost-effectiveness when compared to other technologies (3). These processes rely on the natural ability of microorganisms to carry out the mineralization of organic chemicals, leading ultimately to the formation of $\mathrm{CO}_{2}, \mathrm{H}_{2} \mathrm{O}$ and biomass (12).

Strategies to accelerate the biological breakdown of hydrocarbons in soil include stimulation of the indigenous microorganisms by optimizing the nutrients and oxygen supply and the temperature and $\mathrm{pH}$ conditions (biostimulation), and through inoculation of an enriched mixed microbial consortium into soil (bioaugmentation). In addition to provide these

*Corresponding Author. Mailing address: Av. 24-A, 1515 - Caixa Postal 199. 13506-900, Rio Claro, SP. Tel.: (+5519) 3526-4175 Fax: (+5519) 35264176. E-mail: adrianomariano@yahoo.com.br 
optimum conditions, it is also important to know that the pollutant degradation in soil is influenced by mass transfer phenomena. Providing a way to reduce the sorption of the hydrophobic organic contaminants to the soil matrix can increase the rate and extent of biodegradation (26). For this purpose, the addition of surfactants into the soil aims to enhance the emulsification of hydrocarbons and therefore they have the potential to solubilize hydrocarbons and increase their bioavailability and subsequent biodegradation $(20,24,25,30)$.

In biological treatments it is always necessary to perform laboratory feasibility tests to determine the microbial potential to degrade the pollutants and to evaluate strategies to optimize the degradation rates before the design of real scale in-situ or ex-situ (bioreactors, landfarming and others) treatments. Thus, the purpose of the present study was to investigate possible methods to enhance the rate of aerobic biodegradation (ex-situ treatments) of diesel oil in soil. In this work, the bioremediation processes were applied to a sandy soil contaminated by the leakage of an underground storage tank at a petrol station. Biodegradation of diesel oil was performed using laboratory scale experiments (Bartha biometer flasks). Enhancement of biodegradation was carried out through biostimulation (addition of nitrogen and phosphorus solutions and Tween 80 surfactant) and bioaugmentation (treatment with inoculation of a bacterial consortium isolated from a landfarming). To investigate interactions between optimizing factors, and to find the right combination of these agents, the study was based on full factorial experimental design. Efficiency of biodegradation was simultaneously measured by two methods: respirometric (microbial $\mathrm{CO}_{2}$ production) and gas chromatography to evaluate the biodegradation of total petroleum hydrocarbons (TPH). Acute toxicity tests with Daphnia similis were applied to examine the efficiency of the processes in terms of the generation of less toxic products. The results of this study aim to contribute towards current demands for the development of new processes able to reduce the time usually required for bioremediation.

\section{MATERIALS AND METHODS}

\section{Sampling and Soil characteristics}

Contaminated sandy soil was obtained at a petrol station where a leak in an underground storage tank released, approximately ten years ago, a great amount of diesel oil into the soil and sequentially to the groundwater. The sample was collected from the capillary fringe (depth of $1.60 \mathrm{~m}$ ) and stored at $5^{\circ} \mathrm{C}$. Table 1 summarizes some physicochemical characteristics of the soil. Concentrations of heavy metals are not above the most restricted levels established by Cetesb (São Paulo Environmental Agency - Brazil) and by the Dutch list (11).

Soil characterization. The physicochemical analyses were performed by the laboratory "Instituto Campineiro de Análise de Solo e Adubo (ICASA)", according to the methodology proposed by Embrapa (13), except the following parameters: total nitrogen (laboratory "PIRASOLO - Laboratório Agrotécnico Piracicaba", according to Embrapa (13)); grain size distribution (1) and the moisture content (obtained by the oven drying method).

Table 1. Physicochemical Analyses.

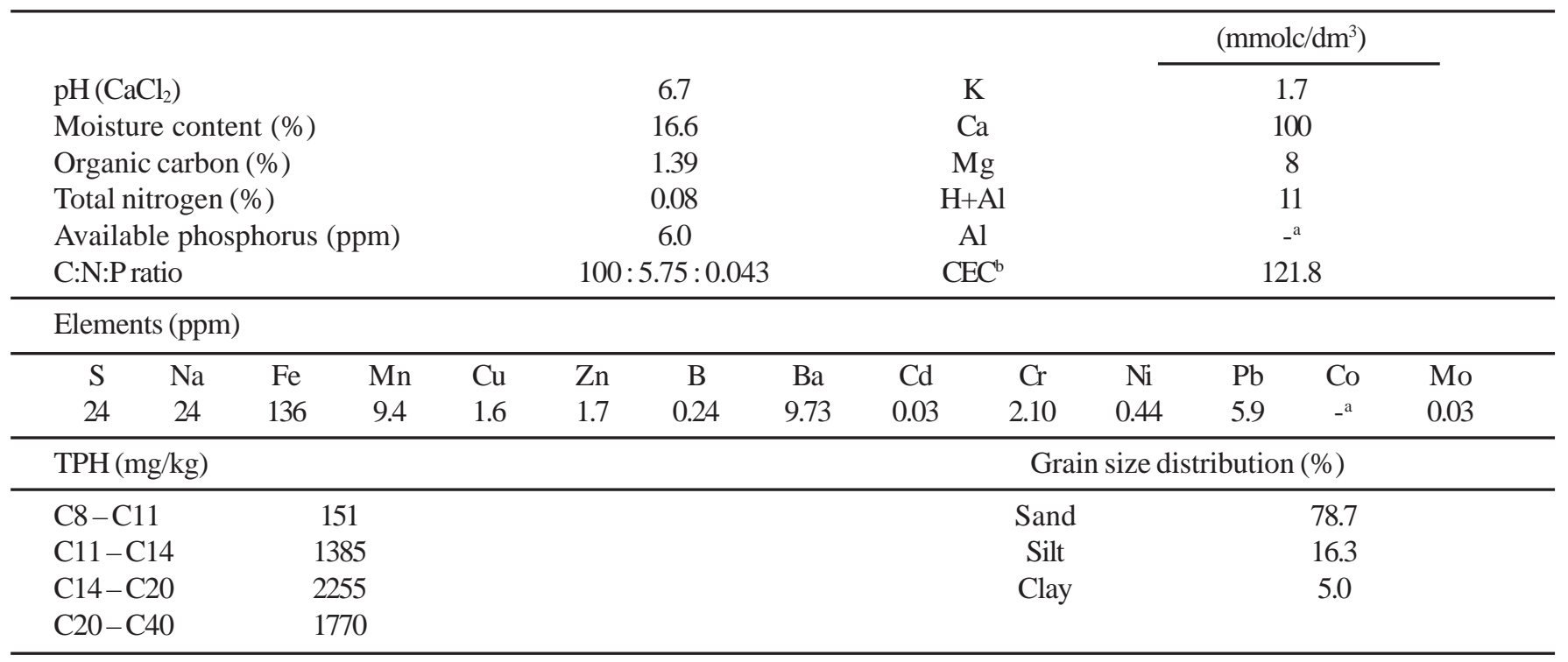

${ }^{\mathrm{a}}$ not detected; ${ }^{\mathrm{b}}$ cation exchange capacity. 
Determination of the total petroleum hydrocarbons (TPH) content was carried out by the "Bioagri Ambiental" laboratory by gas chromatography with the flame ionization detector (FID) according to the US Environmental Protection Agency (USEPA) methodology SW-846/8015.

\section{Biodegradation experiments}

Batch biodegradation experiments were carried out in Bartha biometer flasks $(250 \mathrm{~mL})$ used to measure microbial $\mathrm{CO}_{2}$ production (6). The influence of three variables (nitrogen and phosphorus content (NP), addition of surfactant (S) and bacterial consortium (BC)) on the biodegradation of the pollutants present in the soil was assessed using the full factorial experimental design $\left(2^{3}\right)$ as tool, resulting in 8 experimental conditions (Table 2).

The soil sample was homogenized by a thorough mixing and divided into 8 aliquots, in which the amendment solutions of each treatment were added. The nitrogen and phosphorus correction was performed using $\left(\mathrm{NH}_{4}\right)_{2} \mathrm{SO}_{4}(6080 \mathrm{mg} / \mathrm{kg}$ of soil) and $\mathrm{KH}_{2} \mathrm{PO}_{4}(973 \mathrm{mg} / \mathrm{kg}$ of soil) solutions, respectively. Thus the nutrient ratio (C:N:P) was adjusted to 100:15:1 (8). The bacterial inoculum and the non-ionic Tween 80 surfactant were added at a concentration of $10^{5}$ Colony Forming Units (CFU) per gram of dry soil and $0.2 \%(\mathrm{~m} / \mathrm{m})$, respectively. Considering the addition of amendments, the water content of the soil changed to $21.9 \%$.

The biometer flasks were prepared in triplicates $(3 \times 50 \mathrm{~g}$ of soil) and incubated at $27^{\circ} \mathrm{C}$ in the dark for 55 days. Produced $\mathrm{CO}_{2}$ was trapped in a $10.0 \mathrm{~mL}$ solution of $\mathrm{KOH}(0.2 \mathrm{~N})$, located in the side-arm of the biometer. This solution was periodically withdrawn by syringe, and the amount of carbon dioxide absorbed was then measured by titrating the residual $\mathrm{KOH}$ (after the addition of barium chloride solution $(1 \mathrm{~mL} ; 1.0 \mathrm{~N})$ used to precipitate the carbonate ions) with a standard solution of $\mathrm{HCl}$

Table 2. Experimental conditions generated by the Full Factorial Experimental Design - $2^{3}$.

\begin{tabular}{cccc}
\hline Treatment & NP & S & BC \\
\hline 1 & +1 & +1 & +1 \\
2 & -1 & +1 & +1 \\
3 & +1 & -1 & +1 \\
4 & -1 & -1 & +1 \\
5 & +1 & +1 & -1 \\
6 & -1 & +1 & -1 \\
7 & +1 & -1 & -1 \\
8 & -1 & -1 & -1 \\
\hline
\end{tabular}

$+1: \mathrm{C}: \mathrm{N}: \mathrm{P}$ adjusted to $100: 15: 1$ or addition of surfactant $(0.2 \%(\mathrm{~m} /$ $\mathrm{m})$ ) or inoculum of $10^{5} \mathrm{CFU} / \mathrm{g}$ of dry soil; - 1 : C:N:P not adjusted or no addition of surfactant or inoculum.
$(0.1 \mathrm{~N})$. During this procedure, the biometers were aerated during 1.5 minutes through the ascarite filters.

At the end of the experiment, the replicates of each treatment were thoroughly mixed together for physicochemical, microbiological and toxicity analyses. This procedure was necessary to provide the necessary quantity of soil demanded by the final analyses (without replicates).

The statistical analysis of the results (biodegradation efficiency calculated from the $\mathrm{CO}_{2}$ quantification (3 replicates)) obtained through the experimental design conditions were performed by the software STATISTICA (version 5.0) for Windows. Significance was considered to be at the $p<0.05$ probability level.

Inoculum preparation. The microbial inoculum consisted of three oil-degrading bacteria (Ochrobactrum anthropi, Stenotrophomonas maltophilia and Bacillus cereus) that were previously isolated and identified by Kataoka (19) from a landfarming at the Brazilian oil refinery Replan (Petrobras S/A). The bacteria were grown separately in liquid PCA medium (10 $\mathrm{mL}$ ), incubated for $48 \mathrm{~h}$ at $35^{\circ} \mathrm{C}$. Cells were harvested by centrifugation $(8,000 \mathrm{rpm}$ for $10 \mathrm{~min})$ and the supernatant medium discharged. The resulting cell pellets were resuspended in 5.5 $\mathrm{mL}$ sterile saline solution $(0.85 \%)$ and the same centrifugation procedure was performed. The cell pellets were grouped and the final cell suspension was prepared with the addition of 5.5 $\mathrm{mL}$ saline solution.

Counting of bacteria. Total heterotrophic bacteria were numbered by using the pour plate technique on plate count agar (Acumedia, USA). Plate count of the soil bacterial population was performed as follows: samples of $1 \mathrm{~g}$ of soil were added to $9 \mathrm{~mL}$ of $0.85 \%$ sterile saline solution in essay tubes and agitated mechanically for 2 minutes. After appropriate serial dilutions, $1 \mathrm{~mL}$ of the suspension was spread over the surface of duplicate Petri dishes and incubated for $48 \mathrm{~h}$ at $35^{\circ} \mathrm{C}$. At time zero, the count was performed to treatments 4 (soil + BC), 8 (soil without amendments) and to inoculum suspension. At the end of the experiments, the counting of bacteria was performed for all treatments.

Acute toxicity tests. As a first step to evaluate the acute toxicity, solubilization of the soil was carried out, according to the ABNT Standard 10006 (2), in order to extract possible toxic substances present in the soil. Then, the acute toxicity test was performed on the extractor (water) using Daphnia similis as the test organism, in accordance to the São Paulo Environmental Agency Standard L5.018 (10). At time zero, the test was applied to treatments 6,7 and 8 (representative of the three amendments) and at final time to all treatments. Results were calculated based on the Trimmed Spearman-Karber statistical method (16) and expressed as EC50, $48 \mathrm{~h}$. 
Biodegradation efficiency calculation. The carbon dioxide analyses were used to estimate the total amount of hydrocarbons mineralized during biodegradation experiments. Assuming that $50 \%$ of the biodegraded carbon is converted to $\mathrm{CO}_{2}$ and the other $50 \%$ is added to the soil as humus and biomass (9), the amount of biodegraded carbon can be expressed as:

Total biodegraded carbon $(\mu \mathrm{mol})=2 \cdot \mathrm{CO}_{2}$ produced $(\mu \mathrm{mol})$

And the biodegradation efficiency (BE) as:

$\mathrm{BE} \%=($ Total biodegraded carbon $(\mu \mathrm{mol}) /$ initial soil organic carbon content $(\mu \mathrm{mol})) .100$

The initial soil organic carbon content for each treatment was determined through the carbon mass balance, i.e. by subtracting the produced carbon as $\mathrm{CO}_{2}$ from the measured final organic carbon content (13).

\section{RESULTS AND DISCUSSION}

The cumulative total amounts of $\mathrm{CO}_{2}$ produced by the treated soils over 55-day incubation period and the daily $\mathrm{CO}_{2}$ production are shown in Figures 1 and 2, respectively. There was not lag period in the treatments, probably due to a previous adaptation of the microorganisms to the pollutants and favorable experimental conditions. Comparing the average rate production of $\mathrm{CO}_{2}$ obtained during the first 20 days with that one obtained in the subsequent period $\left(21-55^{\text {th }}\right.$ day), the average rate dropped approximately $45 \%$ (for treatments $1 ; 3 ; 5$ and 7 ) and $23 \%$ (for treatments $2 ; 4 ; 6$ and 8 ). This variation may be caused by a

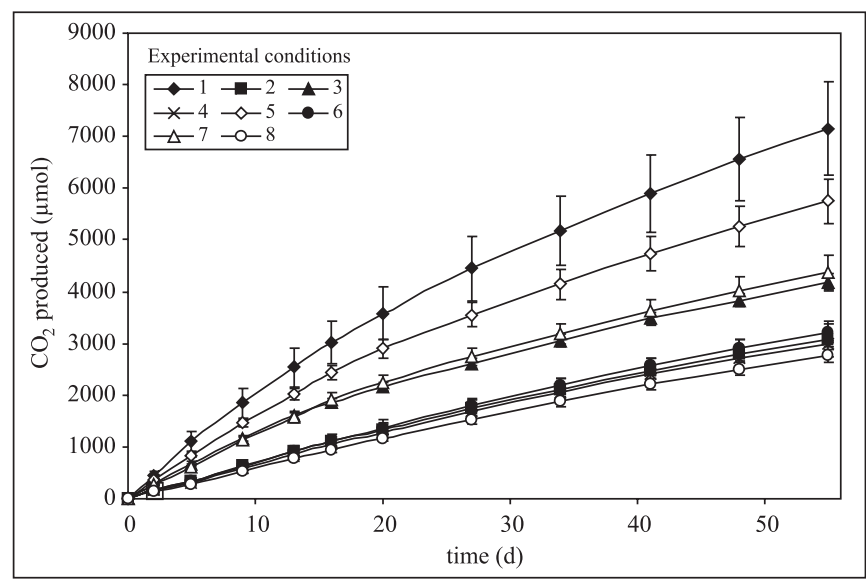

Figure 1. Cumulative total amounts of $\mathrm{CO}_{2}$ produced by the treated soils during incubation. Each error bar represents $1 \mathrm{SD}$ of three replicate experiments.

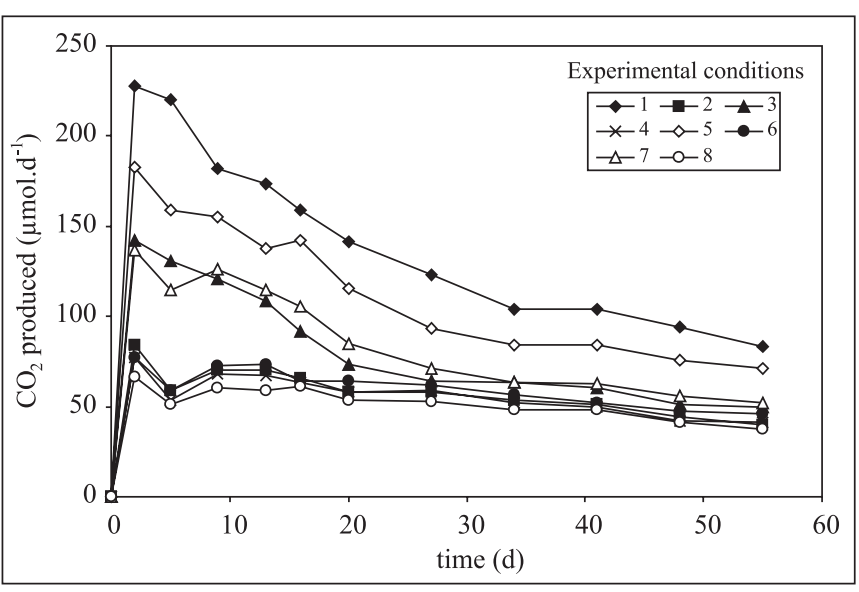

Figure 2. Daily $\mathrm{CO}_{2}$ production during incubation.

transition of carbon sources. As the labile hydrocarbon sources (probably linear and open-chain hydrocarbons) are consumed, their bioavailability decreases. The shortage of these sources forces the microorganisms to adapt to more recalcitrant sources (probably aromatic hydrocarbons with higher molecular weight), resulting in a decrease of the $\mathrm{CO}_{2}$ production. This behavior was more evident in treatments with addition of nutrients (treatments $1 ; 3 ; 5$ and 7), what suggests that the beneficial effect obtained with the nutrient addition is less pronounced in the biodegradation of more recalcitrant sources, as observed by Hencklein (17) studying the biodegradability of refinery oily sludge.

Based on the $\mathrm{CO}_{2}$ production, the biodegradation efficiency (BE) was calculated using Equation 2 (Fig. 3). The biodegradation efficiency calculated using the $\mathrm{CO}_{2}$ data refers to the complete transformation of the hydrocarbons to $\mathrm{CO}_{2}$ (mineralization). If hydrocarbons are partially biodegraded, the quantification of $\mathrm{CO}_{2}$ does not take into account these incomplete processes. Treatments with nutrient amendment $(1 ; 3 ; 5$ and 7) clearly showed the best results (up to $19.8 \%$ ). In Fig. 4, the Pareto Chart, obtained through the experimental design conditions, represents the effects of the variables tested on the biodegradation efficiency. Effects were considered statistically significant for a $95 \%$ confidence level, represented by the dotted line $(\mathrm{p}=0.05)$. Positive values in the Pareto Chart indicate that the variable in question has a favorable effect on the pollutant removal efficiency. The three variables isolated, and the combination of nutrients and surfactant ( 1 by 2 ) influenced positively the biodegradation process.

The relatively larger effect of the nutrients amendment indicates that nutrient availability is an important limiting factor for natural bioremediation of the contaminated soil considered in this work. Biostimulation with addition of fertilizers ( $\mathrm{N}$ and $\mathrm{P}$ ) has been reported as an important factor to enhance soil bioremediation $(14,8)$. Nevertheless, some studies reveal that 


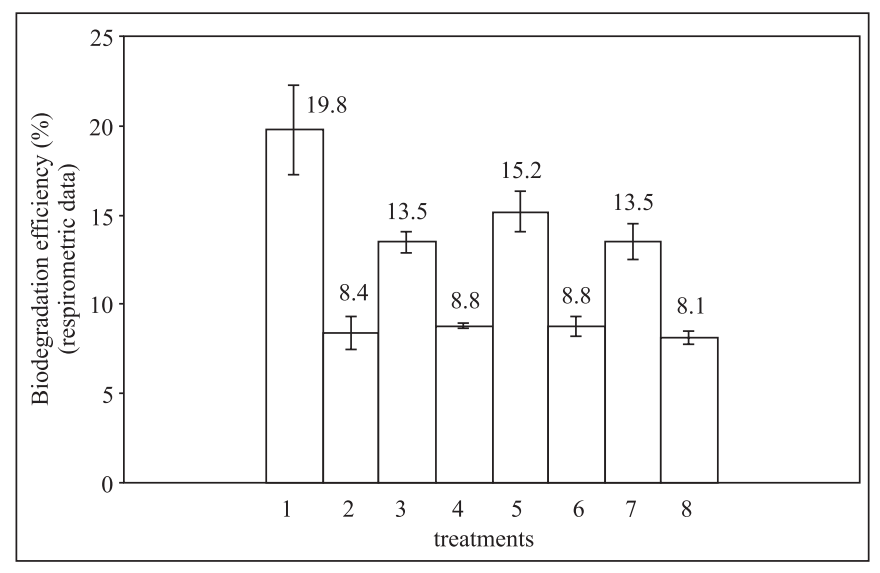

Figure 3. Biodegradation efficiency obtained through the respirometric data. Each error bar represents $1 \mathrm{SD}$ of three replicate experiments.

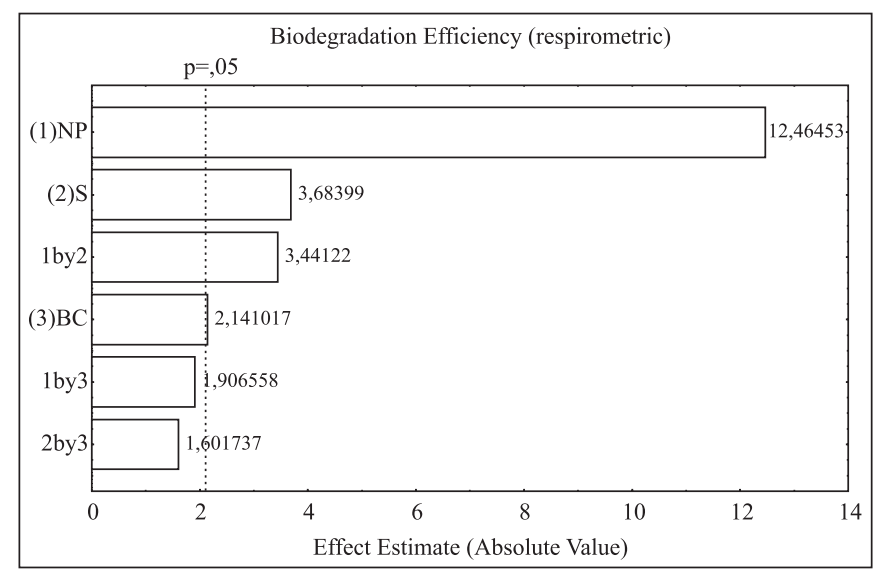

Figure 4. Pareto Chart for the experimental conditions (NP addition of nutrients; $\mathrm{S}$ - surfactant; $\mathrm{BC}$ - bacterial consortium).

the nitrogen and phosphorus correction may have no effect on the decontamination $(17,28)$, or even may represent an inhibitory effect in the biodegradation process by excessive addition $(29,31)$. The nitrogen, when added as ammonium salts, can be toxic to the microorganisms due to the ammonia generation in the soil, which can be lethal in high concentrations and some sources of phosphorus (phosphate and ortho-phosphate) may present diverse effects on the biodegradation depending on their toxicity and solubility (29). According to Walworth et al. (31), the inhibitory levels of nitrogen range from 100 to 4000 $\mathrm{mgN} / \mathrm{Kg}$ of soil. These values are not in agreement with the soil adjustment of $2090 \mathrm{mgN} / \mathrm{Kg}$ carried out in this work.

Biostimulation with the addition of Tween 80 surfactant, intended to increase the bioavailability of the hydrocarbons to the microorganisms, also presented positive effects in the biodegradation efficiency, mainly in the treatments (1 and 5) where the nutrients (principal limiting factor to biodegradation) had been adjusted. Studies concerning the use of surfactant in bioremediation processes present results ranging from stimulation to inhibition of desorption and biodegradation of polluting compounds (30). In this work, the effects of the surfactant on the physiology of the bacteria did not cause inhibition of growth due to a possible surfactant intermediates toxicity neither stimulation of growth caused by a possible use of the surfactant as a co-substrate, since the average bacterial population in treatments with surfactant was not statistically (ANOVA analysis) different from the others.

Biodegradation rates enhancement using the Tween 80 surfactant was also obtained by Kataoka (19), Xie (32) and Mueller et al. (1991) apud Rouse et al. (27). According to Zheng and Obbard (33), Tween 80 is a biodegradable polyxyethylene surfactant and its fate and toxicity in the environment is not of scientific concern. However, Hencklein (17) observed negative effects when applied this surfactant, which may have increased the availability of more toxic compounds present in the refinery oily sludge.

The bioaugmentation with bacterial consortium isolated from a landfarming was the variable that had the smaller positive effect in the biodegradation rates. Comparing treatments 1 and 5 , it is possible to observe that the presence of the bacterial consortium in treatment 1 clearly improved the biodegradation efficiency. This positive effect is also noticeable in the final plate count of the bacterial soil population of this treatment, which showed the higher value of all treatments (Fig. 6), but the average bacterial population in treatments with biaugmentation was not statistically (ANOVA analysis) different from the others, which may be a possible evidence of the poor effect of this variable. Some works reported that inoculation had no positive, or only marginal effects on hydrocarbon biodegradation rates $(4,5,22)$. Microorganisms able to degrade organic pollutants in cultures may fail to function when inoculated into natural environments, because they may be susceptible to toxins or predators in the environment. They may use other organic compounds in preference to the pollutant, or they may be unable to move through the soil to the contaminated site. The successful use of microbial inocula in soils requires that the microorganisms contact the contaminant. Physical adsorption to soil particles or filtration through small pores may limit the transport of organisms (23). In some studies, the bioaugmentation of the bacterial population already present in the soil have achieved the best performance in diesel oil degradation in soil (7).

In terms of TPH removal (Fig. 5), results showed similar behavior to respirometric data, i.e. better treatments were obtained with fertilizer in combination with another amendments. Removal efficiency was clearly influenced positively by these combinations, since treatments without combination $(4 ; 6$ and 


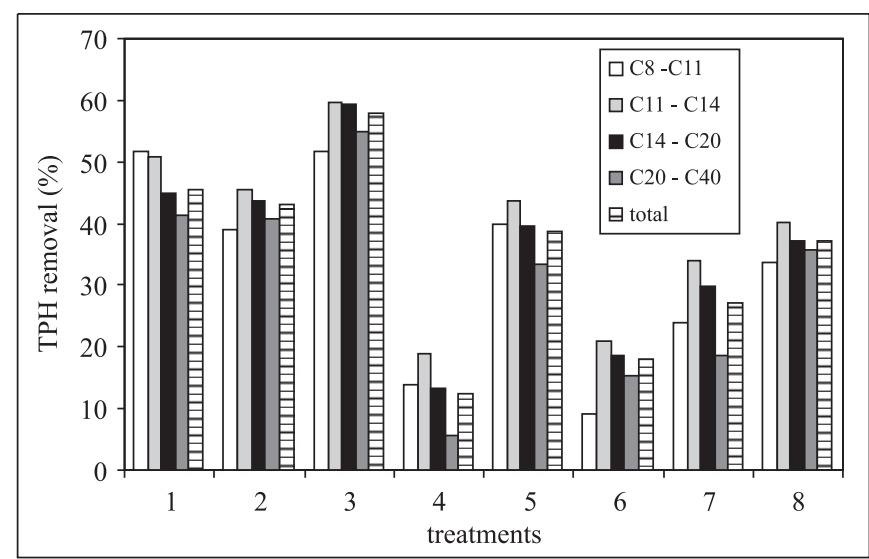

Figure 5. Total petroleum hydrocarbon (TPH) removal efficiency for different treatments.

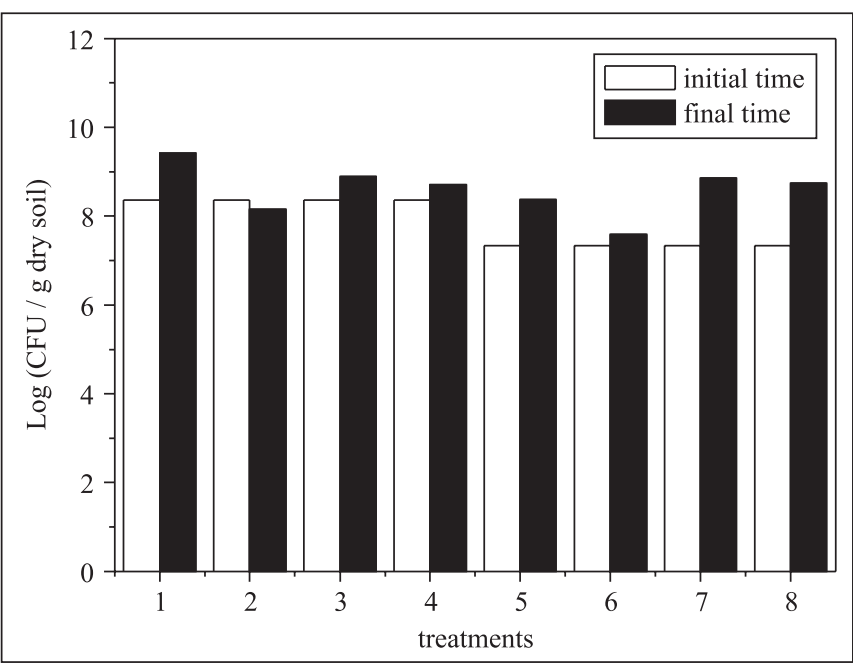

Figure 6. Total heterotrophic bacteria counts in the contaminated soil at initial and final time of treatments.

7) achieved results even worst than treatment 8 (without amendments). The best total TPH (sum of all ranges) removal efficiency of $57.8 \%$ in treatment 3 did not correspond to the treatment with higher mineralization degree (treatment 1 ). This fact indicates differences in the metabolic routes between the microbiota present in treatments 1 and 3. In the latter, certainly, a greater part of the hydrocarbons was transformed, however, not achieving the maximum degree of biodegradation $\left(\mathrm{CO}_{2}\right.$ production). Moreover, the difference of $\mathrm{CO}_{2}$ production between treatments 1 and 3 may also be increased by the presence of Tween 80, a biodegradable surfactant (33). In relation to the TPH fractions, there were no significant differences between biodegradation of light and heavy hydrocarbons as observed by Bento et al. (7).
Marchal et al. (21) report that many studies performed with soil microcosms had incomplete degradation of diesel oil. The partial TPH biodegradation obtained in this work $(57.8 \%)$ in 55 days of treatment is in agreement with the results obtained by Bento et al. (7) that achieved in 84 days a TPH removal of approximately $75 \%$ with similar bioremediation strategies.

In Fig. 6 is represented the plate count of the bacterial soil population performed before and after treatments. In most treatments, the microbial populations at the end of the experiment were approximately 2 to 30 times greater than the initial cell densities. The number of heterotrophic population was not influenced by the bioremediation treatments (ANOVA analysis), as well observed by Bento et al. (7). Hickman and Novak (18) concluded that total microbial biomass was a poor predictor for determining biodegradation potential mainly because the active biomass may differ in species composition and in metabolic regimes.

At the bacterial plate count performed after treatments, the dominance of two cultures, differing by the colour (white and yellow), was observed in terms of numbers of CFU. These cultures were isolated and identified by $16 \mathrm{~S}$ rDNA sequencing (analysis performed by CPQBA/UNICAMP). The white cultures were classified as Staphylococcus hominis and the yellow as Kocuria palustris, both gram-positive cocci. These species have not been previously reported in soil contaminated by hydrocarbons. However, Gomes et al. (15) isolated Staphylococcus aureus from samples of heavy oil.

Table 3 shows the values of $\mathrm{pH}$ and nitrogen and phosphorus consumption at the end of the treatments. The $\mathrm{pH}$ values in treatments without nutrient addition increased (in comparison to the initial value of 6.7). According to Rhaman et al. (25), an increase in $\mathrm{pH}$ suggests the release of by-products during hydrocarbon degradation. This behavior was not observed in treatments with nutrients addition because the $\left(\mathrm{NH}_{4}\right)_{2} \mathrm{SO}_{4}$ fertilizer increases the soil acidity. None of the final $\mathrm{pH}$ values is harmful to biological activity.

Table 3. Values of $\mathrm{pH}$; nitrogen and phosphorus consumption at the end of the treatments.

\begin{tabular}{cccc}
\hline Treatment & Final $\mathrm{pH}\left(\mathrm{CaCl}_{2}\right)$ & $\mathrm{N}\left(\mathrm{mg} \cdot \mathrm{Kg}^{-1}\right)$ & $\mathrm{P}\left(\mathrm{mg} \cdot \mathrm{Kg}^{-1}\right)$ \\
\hline 1 & 6.5 & 760 & 73 \\
2 & 7.4 & 310 & 1 \\
3 & 6.7 & 970 & 69 \\
4 & 7.5 & 310 & 0 \\
5 & 6.7 & 1110 & 71 \\
6 & 7.5 & 380 & 0 \\
7 & 6.8 & 900 & 59 \\
8 & 7.5 & 450 & 0 \\
\hline
\end{tabular}


In relation to the nutrients, the values of the $\mathrm{N}$ consumption suggest a possible correlation between this nutrient and the biodegradation efficiency (respirometric data) and the low consumption of $\mathrm{P}$ in treatments without nutrient adjustment suggests that this element, when in low quantities, was not available for the bacterial population.

The results obtained with the acute toxicity tests are listed in Table 4. Initially, only treatments with nutrients addition presented some toxicity and at final time the treatments showed different levels of toxicity independently of amendments and of biodegradation efficiency achieved. From this observation, it is reasonable to reject any toxic effect derived from the fertilizers and from the Tween 80 surfactant. Since the test was based on extracting the pollutants using water, the majority of the initial hydrocarbons, that have low solubility constant, was poorly transferred to the water. Thus, a possible explanation for the toxicity increase during the microbial conversion of hydrocarbons is the formation of intermediates (probably organic acids) with higher water solubility.

\section{CONCLUDING REMARKS}

Bioremediation strategies to enhance the biodegradation of diesel oil in soil showed satisfactory results. During 55 days of treatment, amendments roughly doubled the biodegradation efficiency in terms of mineralization (19.8\%) with a TPH removal of $45.5 \%$ when all amendments were added. The shortage of nutrients was the principal limiting factor of the process and the increase in biodegradation efficiency with the Tween 80 surfactant suggests that this product was effective in providing bioavailability. The minimal effect of the bioaugmentation with non indigenous bacteria was in agreement with other studies that recommend their use in case of more recalcitrant chemicals or when the local microbial population is insufficient or inadequate.

Table 4. Acute toxicity tests using Daphnia similis.

\begin{tabular}{ccc}
\hline Treatment & \multicolumn{2}{c}{ EC50,48h } \\
\cline { 2 - 3 } & initial & final \\
\hline 1 & 7.16 & 6.91 \\
2 & -1 & 6.32 \\
3 & 7.16 & 7.03 \\
4 & - & 0.83 \\
5 & 7.16 & 4.17 \\
6 & - & 1.78 \\
7 & 7.16 & 0.73 \\
8 & - & 0.17 \\
\hline
\end{tabular}

\footnotetext{
${ }^{1}$ not toxic.
}

\section{ACKNOWLEDGMENTS}

The authors acknowledge the Agência Nacional do Petróleo, Gás Natural e Biocombustíveis (ANP) (PRH-05) for granting a scholarship for the development of the present research, and the petrol station owner.

\section{RESUMO}

\section{Estudo laboratorial da biorremediação de solo de posto de combustíveis contaminado com óleo diesel}

O objetivo do presente estudo foi investigar possíveis métodos para aumentar a taxa de biodegradação aeróbia de hidrocarbonetos (tratamentos ex-situ). Neste trabalho, processos de biorremediação foram aplicados a um solo arenoso com alto nível de contaminação ocasionada por um vazamento de um tanque de armazenamento de óleo diesel subterrâneo em um posto de combustíveis. Experimentos em escala laboratorial (respirômetros de Bartha) foram utilizados para avaliar a biodegradação do óleo diesel. Estímulo da biodegradação foi realizado utilizando-se as técnicas de bioestímulo (adição de soluções de nitrogênio e fósforo ou surfactante Tween 80) e de bioaumento (consórcio bacteriano isolado de um sistema de landfarming). Para investigar as interações entre os fatores otimizadores, e encontrar a melhor combinação entre esses agentes, o estudo foi baseado em um delineamento experimental fatorial completo. A eficiência de biodegradação foi simultaneamente medida com dois métodos: respirométrico (produção de $\mathrm{CO}_{2}$ microbiano) e cromatografia gasosa. Testes de toxicidade aguda com Daphnia similis foram aplicados para examinar a eficiência dos processos em termos de geração de produtos menos tóxicos. Resultados mostraram que todas as estratégias de biorremediação aceleraram a biorremediação natural do solo contaminado e os melhores resultados foram obtidos quando os tratamentos tinham adição de nutrientes. Dados respirométricos indicaram uma máxima mineralização de hidrocarbonetos de $19,8 \%$, obtida com a combinação dos três agentes, com uma remoção de hidrocarbonetos totais de petróleo (TPH) de 45,5\% em 55 dias de tratamento. No final dos experimentos, duas espécies predominantes de bactéria foram isoladas e identificadas como Staphylococcus hominis e Kocuria palustris.

Palavras-chaves: Biorremediação, Solo, Óleo Diesel, Posto de combustíveis.

\section{REFERENCES}

1. ABNT - Associação Brasileira de Normas Técnicas (1984). NBR 7181: Solo - Análise Granulométrica. [Brazilian Association of Technical Standards - NBR 7181. Soil - Granulometric analysis]. Rio de Janeiro, 13p. 
2. ABNT- Associação Brasileira de Normas Técnicas (1987). NBR 10006 - Solubilização de resíduos sólidos. [Brazilian Association of Technical Standards - NBR 10006. Solubilization of solid residues]. Rio de Janeiro, 2p.

3. Alexander, M. (1994). Biodegradation and Bioremediation. Academic Press, San Diego.

4. APS - Applied Biotreatment Association (1989). Case history compendium. Appl. Biotreat. Assoc., Washington, DC.

5. APS - Applied Biotreatment Association (1990). The role of biotreatment of oil spills. Appl. Biotreat. Assoc., Washington, DC.

6. Bartha, R.; Pramer, D. (1965). Features of a flask and method for measuring the persistence and biological effects of pesticides in soil. Soil Sci., 100, 68-70.

7. Bento, F.M.; Camargo, F.A.O.; Okeke, B. (2003). Bioremediation of soil contaminated by diesel oil. Braz. J. Microbiol., 34, 65-68.

8. Cardona, S.; Iturbe, R. (2003). Biodegradación de diesel mexicano por un consorcio de bacterias de un suelo agrícola. DYNA, 138, 1326.

9. Cetesb - Companhia de Tecnologia de Saneamento Ambiental. (1990). Norma Técnica L 6.350 - Solos - Determinação da Biodegradação de Resíduos - Método Respirométrico de Bartha. São Paulo. 9p.

10. Cetesb - Companhia de Tecnologia de Saneamento Ambiental. (1991). Norma L5.018 - Teste de Toxicidade Aguda com Daphnia similis [Company of Environmental Sanitation Technology - Technical Standard L5.018 Acute toxicity test with Daphnia similis]. São Paulo, $33 \mathrm{p}$.

11. Cetesb - Companhia de Tecnologia de Saneamento Ambiental. (2001). Relatório de estabelecimento de Valores Orientadores para Solos e Águas Subterrâneas no Estado de São Paulo. [Company of Environmental Sanitation Technology]. Technical report.

12. Duarte da Cunha, C.; Leite, S.G.F. (2000). Gasoline biodegradation in different soil microcosms. Braz. J. Microbiol., 31, 45-49.

13. Embrapa - Empresa Brasileira de Pesquisa Agropecuária (1997). Manual de Métodos de Análises de Solos. Rio de Janeiro.

14. Gallego, J.L.R.; Loredo, J.; Llamas, J.F.; Vázquez, F.; Sánchez, J. (2001). Bioremediation of diesel-contaminated soils: Evaluation of potential in situ techniques by study of bacterial degradation. Biodegradation, 12, 325-335.

15. Gomes, R.V.; Martins, S.C.S.; Melo, V.M.M. (2004). Produção de biossurfactante por Staphylococcus aureus isolado de uma amostra de petróleo pesado. IX ENAMA - Encontro nacional de Microbiologia Ambiental, Curitiba, Brazil

16. Hamilton, M.A.; Russo, R.C.; Thurston, R.V. (1978). Trimmed Spearman - Karber method for estimating median lethal concentrations in toxicity bioassays. Environ. Sci. Technol., 11(07), 714-719.

17. Hencklein, F.A. (2005). Estabilização de "landfarming" de refinaria de petróleo e aplicabilidade em solos com baixos teores de carbono. Rio Claro, Brasil (Final term-paper. Instituto de Biociências, UnespRio Claro).

18. Hickman, G.T.; Novak, J.T. (1989). Relationship between subsurface biodegradation rates and microbial density. Environ. Sci. Technol., $23,525-532$.
19. Kataoka, A.P.A.G. (2001). Biodegradação de resíduo oleoso de refinaria de petróleo por microrganismos isolados de "landfarming". Rio Claro, Brasil (Ph.D Thesis. Instituto de Biociências, Unesp-Rio Claro)

20. Löser, C.; Seidel, H.; Hoffmann, P.; Zehnsdorf, A. (1999). Bioavailability of hydrocarbons during microbial remediation of a sandy soil. Appl. Microbiol. Biotechnol., 51, 105-111.

21. Marchal, R.; Penet, S.; Solano-Serena, F.; Vandecasteele, J.P. (2003). Gasoline and diesel oil biodegradation. Oil \& Gas Sci. Technol. - Rev. IFP, 58(4), 441-448.

22. Margesin, R.; Schinner, R. (1997). Efficiency of indigenous and inoculated cold adapted soil microorganisms for biodegradation of diesel oil in Alpine soils. Appl. Environ. Microbiol., 63(7), 26602664.

23. Márques-Rocha, F.J.; Hernández-Rodrígues, V.; Lamela, M.T. (2001). Biodegradation of diesel oil by a microbial consortium. Water Air Soil Pollut., 128, 313-320.

24. Rahman, K.S.M.; Rahman, T.J.; McClean, S.; Marchant, R.; Banat, I.M. (2002). Rhamnolipid Biosurfactant Production by Strains of Pseudomonas aeruginosa Using Low-Cost Raw Materials. Biotechnol. Prog., 18, 1277-1281.

25. Rahman, K.S.M.; Rahman, T.J.; Kourkoutas, Y.; Petsas, I.; Marchant, R.; Banat, I.M. (2003). Enhanced bioremediation of n-alkane in petroleum sludge using bacterial consortium amended with rhamnolipid and micronutrients. Bioresour. Technol., 90, 159-168.

26. Rizzo, A.C.L.; Cunha, C.D.; Raimundo, R.S.; Magalhães, M.H.; Lemos, J.L.S.; Millioli, V.S.; Leite, S.G.F.; Santos, R.L.C.; Soriano, A.U. (2003). Identification of the bioremediation limiting factors of a clay bearing soil contaminated with crude oil. $10^{\text {th }}$ Annual International Petroleum Environmental Conference, Houston, USA.

27. Rouse, J.D.; Sabatini, D.A.; Suflita, J.M.; Harwell, J.H. (1994). Influence of surfactants on microbial degradation of organic compounds. Crit. Rev. Environ. Sci. Technol., 24, 325-370.

28. Seklemova, E.; Pavlova, A.; Kovacheva, K. (2001). Biostimulationbased bioremediation of diesel fuel: field demonstration. Biodegradation, 12, 311-316.

29. Trindade, P.V.O.; Sobral, L.G.; Rizzo, A.C.L.; Leite, S.G.F.; Lemos, J.L.S. (2002). Evaluation of biostimulation and bioaugmentation techniques in the bioremediation process of petroleum hydrocarbons contaminated soil. $9^{\text {th }}$ international Petroleum Environmental Conference, New Mexico, USA.

30. Volkering, F.; Breure, A.M.; Rulkens, W.H. (1998). Microbiological aspects of surfactant use for biological soil remediation. Biodegradation, 8, 401-417

31. Walworth, J.L.; Woolard, C.R.; Braddock, J.F.; Reynolds, C.M. (1997). The role of soil nitrogen concentration in bioremediation. In Situ and On-Site Bioremediation, 4(4), 283-288.

32. Xie, W. (2003). Effect of Bioventing Remediatim by surfactant on in-situ oil-contaminated soil. Taiwan, China (M.Sc. Dissertation. NYUST).

33. Zheng, Z.; Obbard, J.P. (2002). Polycyclic aromatic hydrocarbon removal from soil by surfactant solubilization and Phanerochaete chrysosporium oxidation. J. Environ. Quality, 31, 1842-1847. 